\title{
Surrealna Zagłada Wokół Egy halott álmaiból Stefánii Mándy Perspektywa genderowa w węgierskiej poezji o Zagładzie
}

\section{Ucukrowany margines. O nieobecnych pisarkach nad Dunajem}

W 2013 roku Anna Menyhért, jedna z najważniejszych badaczek literatury kobiecej na Węgrzech, podjęła temat nieobecności pisarek w opracowaniach poświęconych naddunajskiej historii literatury. W eseju Saját hagyomány („Własna tradycja”) uczona wnikliwie czytała nie tylko podręczniki akademickie, ale także podręczniki szkolne, śledząc, które nazwiska kobiet znalazły się w podstawie programowej. Wnioski płynące $z$ tych analiz wskazywały jednoznacznie, że „kobiety nie piszą”, że „pamiętanie o kobietach” nie jest naturalnym gestem społecznym pomagającym Węgrom budować ich własny wizerunek.

To kolektywna amnezja. Pisarki nie trafiają do kanonu. Nie budują tożsamości. Nie są czytane. Nie rozmawia się o nich. Nie uczy się o nich w szkołach. Nie dotyczy to jedynie węgierskich pisarek, bo za granicą jest podobnie. Niepamiętanie o kobietach zawłaszcza coraz większe terytorium [...]. Nawet jeśli znajdzie się miejsce, w którym można by zaprezentować kilka nazwisk zagranicznych autorów, zawsze są to mężczyźni. Nie ma kobiet. Pasternak, ale nie Cwietajewa ${ }^{2}$.

${ }^{1}$ A. Menyhért: A női irodalmi hagyomány. Erdős Renée, Nemes Nagy Ágnes, Czóbel Minka, Kosztolányi Harmos Ilona, Lesznai Anna. Budapest 2013, s. 15. Wszystkie przekłady, jeśli nie zaznaczono inaczej, są mojego autorstwa - K.P.J.

2 Tamże, s. 14. 
Uwagi Menyhért krążyły też wokół charakterystycznych cech „męskiego” i „kobiecego” pisarstwa. Przywołując pary pojęć wyliczonych po raz pierwszy przez Hélène Cixous - powagę, patriotyzm, patos, tragizm, intelektualizm i logikę jako wyznaczniki pisarstwa męskiego oraz kobiecość, lekkość, brak powagi, bujanie w obłokach, silną więź z naturą, uczucia, brak logiki oraz chaos właściwe twórczości kobiet ${ }^{3}$ - Menyhért potwierdziła również swoje obawy dotyczące braku odpowiednich narzędzi pozwalających na obiektywne badanie literatury. Takich, które programowo niwelowałyby promaskulinistyczny dobór utworów i włączałyby do panoramy artystycznej marginalizowane dotąd pisarki. Badaczka nie miała jednak wątpliwości, że w tej „tradycji zapominania” (felejtés hagyománya) kanon literacki, który winien być „wyznacznikiem i wzorcem” (Mihály Szegedy-Maszák) ${ }^{4}$, odmawiał piszącym kobietom prawa do pełnego udziału w tworzeniu historii literatury i budowaniu obrazu rzeczywistości widzianej poprzez jej pryzmat. Proces ten wzmacniają społeczne przekonania o niższości gatunków preferowanych przez autorki, są to bowiem „tzw. kobiece gatunki - dziennik, memuar, życiorys, listy, emocjonalne wiersze, ucukrowane historie, które z definicji się marginalizuje"5 - konstatowała Menyhért.

Problem ten staje się niezwykle istotny, gdy mamy do czynienia z literaturą pisaną pod wpływem doświadczeń granicznych, gdy tekst (ten deprecjonowany dziennik, wspomnienie, list, rozmowa etc.) staje się jedynym dokumentem o rzeczywistości, na przykład unikatowym świadectwem czasów wojny. Wówczas podział literatury według kategorii płci, skutkujący wykluczaniem piszących kobiet z debaty, znacząco deformuje obraz świata, który, opowiadany przez mężczyzn, układa się w narracje o czynach heroicznych i bohaterskich, co oznacza pomijanie problemów codziennych i trudu przeżycia. W 2006 roku Swietłana Aleksijewicz pisała:

Było już wiele wojen - małe i duże, znane i nieznane. A jeszcze więcej o nich napisano. Tyle, że... Pisali mężczyźni i o mężczyznach - to było od razu jasne. Wszystko, co wiemy o wojnie, powiedział nam „męski głos”. Wszyscy tkwimy w niewoli „męskich” wyobrażeń i „męskich” doznań wojennych. „Męskich” słów. Kobiety milczą [...]. Kiedy mówią kobiety, nie ma albo prawie nie ma tego, o czym zwykle czytamy i słuchamy: jak jedni ludzie po bohatersku zabijali innych i zwyciężali [...]. Kobiety opowiadają inaczej i o czym innym. „Kobieca” wojna ma swoje własne barwy [...]. Ich wojna pozostała nieznana ${ }^{6}$.

${ }^{3}$ Zob. H. Cixous: Śmiech meduzy. Przeł. A. NasıŁowska. „Teksty Drugie” 1993, nr 4/5/6, s. 147-166.

${ }^{4}$ Zob. M. Szegedy-Maszák: A bizony(talan)ság ábrándja: kánonképződés a posztmodern korban. In: TenżE: „Minta a szönyegen”: a müértelmezés esélyei. Budapest 1995, s. 76-89.

${ }^{5}$ A. Menyнért: A nöi irodalmi hagyomány..., s. 20-21.

${ }^{6}$ S. Aleksijewicz: Wojna nie ma w sobie nic $z$ kobiety. Przeł. J. Czech. Wołowiec 2010, s. 9-10. 
Kiedy jednak przyjrzymy się pozycji kobiet w tekstach przedstawiających ich doświadczenia, zauważymy jeden z głównych problemów literackich reprezentacji wojny i Zagłady: albo wybieramy uwspólniony głos (bez uwzględniania płci narratora), który stawia sobie za cel opisanie żydowskiego losu, albo rozdzielamy zapisy na męskie i kobiece, co niesie z sobą określone konsekwencje.

Z jednej strony - piszą redaktorki tomu Women and the Holocaust... - w badaniach nad Holokaustem płeć męska i żeńska traktowane są jako jeden, wspólny żydowski podmiot [Jewish subject], który jest ofiarą, członkiem ruchu oporu i tym, kto przeżył ten sam nieludzki reżim. $Z$ drugiej strony zaś badania naukowe skupiają się na matczynej i seksualnej cielesności żydowskich kobiet, podkreślają kobiecą inność, uwidaczniającą się w typowo kobiecych doświadczeniach, takich jak: przemoc seksualna, ciąża, menstruacja, prostytucja itd.?.

Jak widać, strategie literaturoznawcze, których celem jest rozróżnianie doświadczeń obu płci - najczęściej w scenach dotyczących cielesności (ciąża, poród) - mogą, paradoksalnie, wspomagać wtórne uschematyzowanie. Relacje związane z granicznym doznawaniem kobiecości siłą rzeczy dominują nad pogłębionymi filozoficznie refleksjami o istocie istnienia, których brak zawsze był punktowany przez historyków literatury jako wystarczający powód wyłączania pisarstwa kobiecego z kanonu.

W literaturze węgierskiej, podobnie jak w narodowych literaturach innych krajów środkowoeuropejskich, doświadczenie wojenne opisywane przez kobiety pochodzenia żydowskiego jest obciążone dodatkowym wykluczeniem. Po pierwsze, w kanonie literatury wojennej i obozowej (chociaż w literaturoznawstwie węgierskim nie wyszczególnia się gatunku „literatura obozowa”) teksty prezentujące kobiecą perspektywę należą do wyjątków. Mogłabym tutaj wskazać jedynie: prawie nieznaną obozową powieść Teréz Rudnóy Szabaduló asszonyok. A szabadság első 24 órája (1947) ${ }^{8}$ Hajtükanyar (1974) Márii Ember oraz dziennik Budapesti napló. 1944. november-1945. január (1983) Borbáli Szabó. Dopiero na początku XXI wieku ukazały się dwa tomy antologii krótkich tekstów dotyczących codzienności żydowskich dziewczynek i kobiet (Sós kávé w 2007 roku i Lányok, anyák w 2013 roku), hybrydyczny poemat Egy halott álmaiból (z 1945 roku, opublikowany w 2000 roku) Stefánii Mándy, Anima Rerum. A dolgok lelke (2005) Évy Fahidi, Köszönet az életre (2008) Judith Magyar Isaacson, Bünbakok (2010) Aranki Siegal, Ketten (2010) Ágnes Barth, dzienniki:

${ }^{7}$ A. Petö, L. Hecht, K. Krasuska: Introduction. In: Women and the Holocaust: New Perspectives and Challenges. Eds. A. Petö, L. Нecht, K. Krasuska. Warszawa 2015, s. 14.

${ }^{8}$ Pisałam o losach tej autorki i jej powieści w szkicu: K. Piotrowiak-Junkiert: Eksperyment socjograficzny w narracji kobiecej o Zagładzie: Teréz Rudnóy „Szabaduló asszonyok”. A szabadság első 24 órája. In: A hungarológia ma: nyelvészet, kultúra és oktatás - Hungarologia dzisiaj: językoznawstwo, kultura i dydaktyka. Szerk. I. Koutny, K. Piotrowiak-Junkiert, P. KornaTOWSKi, Sz. NÉmeth. Poznań 2017, s. 281-288. 
Éva lányom (2011) Ágnes Zsolt i Kismama sárga csillaggal (2015) Anny Dévényi Sándorné oraz tomik wierszy Szabadulók. 1944-1945 (2018) Magdy Soós. Do wyliczonych tytułów można dodać także pojedyncze utwory Zsuzsy Béney, Magdy Székely i Ágnes Gergely.

Po drugie, temat żydowski jest jednym z najbardziej przemilczanych tematów literatury węgierskiej po 1945 roku i sytuacji tej nie zmieniła nawet przemiana ustrojowa w 1989 roku $^{9}$. Literackie relacje o wydarzeniach wojny były marginalizowane nie tylko ze względu na płeć, ale także z uwagi na temat. W miniaturze autobiograficznej Konwergencja Nicole Katz pisała: „Bycie kobietą i Żydówką to dwie różne sprawy [...]. Jedno oznacza ciężar, drugie jest przekleństwem [...]"10. Ta podwójność wykluczenia $\mathrm{w}$ istotny sposób wpłynęła na świadomość czytelniczą na Węgrzech, ponieważ brakowało narzędzi intepretacyjnych. Teksty prezentujące żydowską perspektywę feministyczną krążyły samotnie po orbitach męskich narracji, wymykając się im tematycznie i nierzadko formalnie, by w końcu z powodu braku recepcji znaleźć się na obrzeżach kanonu i popaść w niebyt, jako narracje źle obecnego tematu. „Przez lata nikt nie był ciekawy osobistych doświadczeń kobiet - bo ich głos zagłuszył chór męskich narracji. My, czytelniczki, długo wierzyłyśmy, że po Primo Levim, Jeanie Amérym i Imrem Kertészie nie zostało już nic do powiedzenia" - pisała w przedmowie do drugiego tomu „Niewypowiedzianych historii kobiet” Katalin Pécsi ${ }^{11}$.

Wydaje się zrozumiałe, że w sytuacji, kiedy tekstów reprezentujących kobiece doświadczenie wojny drukowano bardzo mało, automatycznie zmieniała się świadomość artystyczna - autorki powracające ${ }^{12}$ do wojennych wspomnień inaczej rozplanowywały akcenty, starając się maksymalnie wykorzystać i tak już ograniczoną obecność kobiecego pisarstwa w tym nurcie literatury. Teksty literackie musiały odpowiednio „autentyzować” (określenie Irene Kacandes) ${ }^{13}$

${ }^{9}$ Jednym z najbardziej zaskakujących dowodów potwierdzających tę sytuację jest popularność grupy Holokauszt és a családom (Holokaust i moja rodzina) założonej z inicjatywy Mátyása Eörsiego na początku 2014 r. na Facebooku. Grupa stała się pierwszym forum węgierskich Żydów, miejscem, gdzie w niedługim czasie pojawiły się tysiące osobistych relacji, wydanych później w pokaźnym, prawie pięćsetstronicowym tomie: A Holokauszt és a családom. Szerk. K. FénYes, M. Szalay. Budapest 2015.

${ }^{10}$ N. Katz: Konvergencia. In: Sós kávé. Női elmesélhetetlen történetek I. Szerk. K. PÉcsi. Budapest 2007, s. 145.

${ }^{11}$ K. PÉCsI: Hallgatások és elhallgatások útvesztöjében. A szerkesztő elöszava. In: Lányok és anyák. Elmeséletlen női történetek II. Szerk. K. PÉcsi. Budapest 2013, s. 7.

${ }_{12}$ Dotyczy to wyłącznie tekstów pisanych z czasowego dystansu. Pisarki tworzące równolegle z wydarzeniami nie budowały tak rozmyślnej strategii, nie miały jeszcze wiedzy o tym, jak będzie wyglądała panorama tekstów poświęconych wojnie.

${ }^{13}$ Irene Kacandes posłużyła się określeniem „autentyzowania/uwiarygadniania” (authenticating) w kontekście narracji dzieci ocalonych, które potwierdzały swoją "prawdomówność" i poznawały przemilczaną historię rodziny dzięki licznym paratekstom: mapom, rycinom, zdjęciom, słowniczkom pojęć. Por. I. KaCAndes: "When Facts are Scarce”. Authenticating Strategies in Writing by Children of Survivors. In: After Testimony. The Ethics and Aeastethics of Holocaust Narrati- 
zarysowane tło historyczne i społeczne (o których przecież się nie mówiło), a ambicjonalne podejście do pisania sprawiało, że powstałe utwory cechowały często bardzo interesujące rozwiązania formalne.

Mimo tak szeroko zakrojonych wysiłków artystycznych węgierskich pisarek czytanie ich dzieł niezmiennie wiąże się z przymusem sztukowania domniemanego dyskursu, który nigdy nie miał szansy na kompletność i stale wymaga rekonstruowania świadomości oraz tożsamości autorek na podstawie rozproszonych fragmentów literackich. W niniejszym szkicu przyjrzę się jednemu z oryginalniejszych tekstów kobiecych poświęconych Zagładzie - Egy halott álmaiból („Ze snów umarłej”, 1947, druk w 2000 roku) Stefánii Mándy.

\section{Ku wyobraźni surrealnej}

Łatwo jest przeoczyć to króciutkie, poświęcone pobytowi w obozie dzieło, pisarka - jako pedagożka, historyczka sztuki i psycholożka - zajmowała się bowiem w swoich książkach przede wszystkim analizą dorobku wielkich artystów węgierskich (jest autorką dwóch legendarnych monografii poświęconych Lajosowi Vajdzie), a po usunięciu ze Związku Pisarzy Węgierskich zarabiała, tłumacząc i pisząc wiersze dla dzieci. Po wojnie opublikowała tylko trzy ${ }^{14}$ tomy liryków adresowanych do dorosłych. Pierwszy, A kés, a kéz, a hal (wydany w Paryżu), w 1970 roku, a kolejne - Az ellopott történelem i Scintilla - już po upadku komunizmu, w 1992 i 1999 roku $^{15}$. Warto zaznaczyć, że drugi zbiór był rozszerzoną wersją pierwszego, więc dorobek poetycki Mándy zmieściłby się bez trudu w jednej, o nieprzesadnej objętości książce.

O Zagładzie napisała niewiele, zaledwie kilka stron prozy poetyckiej Egy halott álmaiból („Ze snów umarłej”). Rozproszone odwołania do świata obozów pojawiały się jednak w wielu wierszach, ponieważ „niedające się złagodzić i wygasić wspomnienie" uczyniła "tonem podstawowym [alaptónus] swojej liryki” jak pisał w szkicu „A csonka csönd szólni marasztal”. Mándy Stefánia pályaképe Attila Juhász. Badacz zwrócił uwagę na powracający w utworach imperatyw pracy nad pamięcią za pomocą ciągle nowych narzędzi językowych i formalnych:

ve for the Future. Eds. J. Lothe, S.R. Suleiman, J. Phelan. Ohio 2012, s. 162-197. W przypadku kobiecych narracji na Węgrzech „uwierzytelnianie” miało służyć dowiedzeniu wysokiej wartości zapisów, które uzupełniają znany z męskich narracji świat wojenny, czym pisarki argumentowały także zasadność swoich motywacji artystycznych.

${ }^{14}$ Przed wojną Mándy wydała tom A lélek lép, lebben suhán (Budapest 1941).

${ }^{15}$ S. MÁndy: A kés, a kéz, a hal. Párizs 1970; TAŻ: Az ellopott történelem. Versek 1944-1992. Budapest 1992; TAż: Scintilla (versek). Budapest 1999. 
Prezentacji pojedynczego losu i poszukiwaniu drogi często towarzyszyły formy pierwszej osoby liczby mnogiej. Zastosowanie tej formy wynikało ze wspólnotowej świadomości, więzi z ucierpiałymi w obozie, z ofiarami, czyli $\mathrm{z}$ diasporą ocalonych, ale $\mathrm{w}$ istocie było narzędziem globalnej uniwersalizacji. Jednym z najważniejszych przejawów siły kształtującej podmiot jest pamięć. Chociaż wspomnienia są przytłaczające [...], emocje i myśli z nich zrodzone są dla poetki jednym z najważniejszych składników inicjujących ars poetica, a niekiedy nawet samodzielną substancją poetycką ${ }^{16}$.

Zdaniem Juhásza, Mándy wykonuje w swojej pamięci kilka czynności stających się metaforami relacji pomiędzy „ja” a tożsamością ufundowaną na konkretnych przeżyciach: autorka tnie, rzeźbi, ryje, żłobi, struga i pogrąża się we wspomnieniach. Bycie ofiarą oznacza, że rozważanie sensu śmierci traktować trzeba jako problem podstawowy, nieunikniony. W tekstach poetki, jak przekonuje badacz, proces wspominania odbywał się dzięki wprowadzeniu dwóch równoległych porządków. Pierwszym była gęsta sieć metafor/symboli (chmura, niebo, ptak, kość, rana, droga, wieża, baranek), drugim - koncept stworzenia własnego języka pisania o Auschwitz, polegający na wyliczeniach oksymoronów (na przykład „jeges láng” - 'mroźny płomień’) 17 .

O ile wyobraźnia poetycka Mándy sięgała do osiągnięć innych pisarzy (Paul Celan, Milán Füst, János Pilinszky, Sándor Weöres), o tyle w materii słownej i inwencji genologicznej przetarła nowe, detabuizujące szlaki. Największym osiągnięciem prozy poetyckiej autorki był tekst „Ze snów umarłej”, dzięki któremu zmienił się horyzont literackiej reprezentacji obozów. W 1945 roku poetka stworzyła utwór zupełnie zaskakujący - nie wybrała charakterystycznych dla pierwszej fazy pisarstwa o obozach (jak przekonywała Judit Tydor-Baumel) autentyczności i obiektywizmu ${ }^{18}$, ale surrealistyczną wizję o bardzo bogatej warstwie symbolicznej, gdzie konsekwentnie wyłożyła teorię „prymatu słowa”, wokół której orbitowały także inne jej teksty.

Nie wiemy wiele o pobycie Mándy w obozach. Wiosną 1944 roku została przydzielona do pracy w fabryce cegieł w Budakalász, skąd deportowano ją do Auschwitz, a później do obozów pracy w Liebau (Lubawka pod Jelenią Górą) i w Laske, gdzie pracowała w fabryce broni. W 1995 roku wspominała:

Po powrocie do kraju, w maju [1945 roku - K.P.J.], spędziłam kilka dni w Balatonboglár, gdzie spisałam swoją traumę czasu wojny. Tekst noszący tytuł Egy halott álmai („Sny umarłej”) miał się ukazać w wydawnictwie Anonymus.

${ }^{16}$ A. JuHÁsz: „A csonka csönd szólni marasztal”. Mándy Stéfánia pályaképe. „Műhely” 2001, nr 6, s. 33 .

17 Tamże, s. 35.

${ }_{18}$ Zob. J. Tydor-Baumel: Gender and Family Studies of the Holocaust: the Development of a Historical Discipline. In: Life, Death, Sacrifice. Woman and Family in the Holocaust. Ed. E. Herzog. Jerusalem-New York 2008, s. 21-36. 
Kiedy jednak trafił do drukarni, wydawnictwo ogłosiło upadłość. Temat, jak wiemy, na wiele lat stał się tabu. Od tego czasu rękopis nie ujrzał światła dziennego $^{19}$.

Z bardzo lakonicznych wspomnień trudno wywnioskować, czy powstaniu tekstu towarzyszyła szczególna aura intelektualna, czy Mándy czytała równolegle konkretne książki, które mogły zainspirować ją do stworzenia tak wymagającego artystycznie utworu. Sama wielokrotnie pisała, że jedną z kluczowych dla jej tożsamości lektur był artykuł Szakzsidóság vagy zsidó világnézet Béli Tábora (1907-1992), filozofa i teoretyka „kwestii żydowskiej”, opublikowany w 1943 roku na łamach pisma „Ararát”. Pisarka poznała rozprawę jeszcze przed deportacją. „Tekst ten o czymś we mnie przesądził"20 - pisała w 1995 roku. Po powrocie do Budapesztu Mándy odszukała autora artykułu, który wrócił z wojny 22 czerwca 1945 roku. Wcześniej przebył pieszo 1200 kilometrów w zakolu Donu, był więźniem trzech obozów koncentracyjnych, a w stolicy Węgier pojawił się wraz z grupą osieroconych dzieci z Terezina, gdzie kierował Kinderheimem. Pierwsze spotkanie Mándy i Tábora odbyło się w sierpniu (przypadek sprawił, że oboje mieszkali w jednym budynku), we wrześniu 1945 roku byli już małżeństwem.

Ich najważniejsze prace dotyczące kondycji żydowskiej (A zsidóság útja, 1939) i doświadczenia Auschwitz („Ze snów umarłej”, 1945) powstały, zanim się poznali, a Mándy nie potwierdziła nigdy, że czytała książkę męża przed napisaniem „Ze snów umarłej”, więc w analizie utworu pisarki będę odnosiła się tylko do filozofii „bycia Żydem” Tábora przedstawionej w tekście opublikowanym w „Ararát”. Koncept równoległej lektury pozwala dostrzec wstrząsający ideowo hiatus między zapleczem teoretycznym, z którym identyfikowała się Mándy (wyeksponowanym w artykule Szakzsidóság avagy zsidó világnézet („Zawód-Żyd albo żydowski światopogląd”)), a doświadczeniem „żydostwa” (zsidóság) ${ }^{21}$ autorki przepracowywanym w jej utworach.

W 1943 roku Tábor postawił pytanie o zasadność traktowania Żydów węgierskich jako osobnej wspólnoty, czyli grupy społecznej, która kieruje się konkretnym zapleczem „treściowym”. Użył słowa „tartalom” - pytał o ideową „zawartość". Według węgierskiego filozofa bycie Żydem można było wówczas sprowadzić do udzielenia odpowiedzi twierdzących na kilkanaście pytań, które z czasem stały się modelem definiującym kondycję Żydów na Węgrzech w przededniu wojny. Przytoczę główne zagadnienia tworzące ten model tożsamościowy.

19 S. MÁndy: Mozaikrészecskék egy Egészhez. Tábor Béláról. „Szombat” 1995, nr 7. Dostępne w Internecie: https://www.szombat.org/archivum/mozaikreszecskek-egy-egeszhez [data dostępu: 20.02.2019].

20 Tamże.

${ }^{21}$ Węgierski rzeczownik zsidóság („żydostwo”) nie jest waloryzowany negatywnie. Oznacza wszystko, co wiąże się z religią, obyczajami, uwikłaniem społecznym czy praktykami artystycznymi Żydów; najczęściej używany jest do określenia wspólnoty Żydów danego obszaru, miasta. 
Żydzi to ci - twierdził Tábor - którzy są Żydami z bezczynności, [...] którzy żyją ze swojego żydostwa, [...] którzy za nie obrywają, którzy są Żydami w imię solidarności, odwagi, [...] imperatywu moralnego [...].

Żydzi to ci, dla których żydostwo jest wyznaniem, ale nie wiarą, którzy widzą w byciu Żydem pewną formację [...], traktują swoje żydostwo jako narodowość, ale nie odczuwają względem tego pojęcia żadnych uczuć, tym bardziej miłości [...], dla których „żydostwo” jest oderwane od jakiegokolwiek konkretu, jest zawieszonym w malignie pustym słowem, ale mimo to uwielbiają tę malignę.

Ale, kim są ci, dla których bycie Żydem to pożywka, osobista sprawa, wiara i światopogląd? Kto jest tym, który jest Żydem, bo czuje, że pragnie też żydostwa, będąc wolnym, z przekonania? ${ }^{22}$

Przywołane tezy miały bezpośredni związek z sytuacją społeczną węgierskich Żydów, z antysemickimi komentarzami towarzyszącymi działalności artystycznej większości twórców. Tábor pisał głównie po to, by uświadomić swoim rodakom, na czym polega esencja jego pochodzenia, z czego wynika obecność Żydów nad Dunajem, a wreszcie, by metodycznie wytrącić z rąk węgierskich narodowych socjalistów wszystkie hasła polityki nienawiści rasowej (tak powstała jego legendarna książka $A$ zsidóság két útja) ${ }^{23}$.

Mándy poznała ten tekst krótko przed deportacją, można więc przypuszczać, że w zasadniczej mierze ukształtował on jej pogląd na własną przynależność etniczną i tożsamość, co może oznaczać, że w swoim literackim eksperymencie poświęconym doświadczeniu Auschwitz odnosiła się, chcąc nie chcąc, do modelu Tábora, ale już przez pryzmat własnych przeżyć, które najkrócej można by scharakteryzować parafrazą słów filozofa: „Żydem jest ten, kogo skazuje się na śmierć i społeczne wykluczenie”.

Stałe odnoszenie własnej twórczości i tożsamości artystycznej do dorobku intelektualnego męża potwierdza również fakt, że opublikowane w 2000 roku na łamach „Múlt és Jövő” „Ze snów umarłej” poprzedził fragment tekstu Tábora, brzmiący następująco:

Czym jest przeszłość, którą przeżyliśmy

i z którą musimy się zmierzyć? Minęła jak wszystko, zapuszcza korzenie

w rozgałęziającej się i złudnej głębi, ale nie wszystko minęło.

Istnieje bowiem słowo łączące w okrutną całość, rozsadzając

bezmiar przeszłości i głębię rojące sobie, że jest centrum, tym słowem jest:

Auschwitz. Czy używamy go jako symbolu, by

zobrazować wszystkie straszne poglądy,

${ }^{22}$ B. TÁвоR: Szakzsidóság vagy zsidó világnézet. „Ararát” 1943. Dostępne w Internecie: http://lajosszabo.com/SZEL/szakzsidosag.pdf [data dostępu: 08.04.2019].

${ }^{23}$ Co prawda, we wstępie do książki Tábor twierdził, że pisze ją „węgierski Żyd dla żydostwa i o żydostwie", ale była przecież szeroko czytana i odwoływano się do niej we wszystkich tekstach poświęconych mniejszościom wyznaniowym i obyczajowym na Węgrzech. Zob. B. TÁвor: A zsidóság két útja. Budapest 1939, s. 5. 
które w nieodległej przeszłości doprowadziły do kosmicznego pęknięcia? Byłby to grzech przeciw świętości konkretu: profanacja historii. Auschwitz jest najważniejszym wydarzeniem - znacznie ważniejszym niż bycie jądrem wszystkich wydarzeń bo samo stało się symbolem. I dlatego nie ma pilniejszego zadania niż rozpoznanie jego wagi: mierzenie Auschwitz dostarcza symboli wybrzmiewających pod jego nazwą. Tak długo pustoszą, jak długo nie udzieli się im głosu. ${ }^{24}$

Motto utworu jednoznacznie wskazuje na dwa główne cele pisarki. Pierwszym jest wytwarzanie języka polegające na nazywaniu pojęć i doświadczeń, które oswaja się poprzez ich opisywanie. Drugi cel to mierzenie się z przeszłością podlegającą sprzecznym procesom - mijania i bycia nieustającą teraźniejszością. Mándy wybiera estetykę onirycznej wizji, a nawet matrioszkowej struktury. Kolejne obrazy obozu ukryte są w coraz głębszych pokładach sennej wędrówki narratorki, o czym świadczą choćby podtytuły „Ze snów umarłej”: „Rzeczywistość”, „Sen” i „Co śniłam we śnie”. W dodatku, rozdziały są poprzedzone i zwieńczone fragmentami poetyckimi, które bezpośrednio osadzają czytelnika w precyzyjnie zaprojektowanej tekstowej rzeczywistości i pozwalają mu z niej wyjśćc.

\section{Wyspa, Nietoperz, ciało}

Pierwszy obraz poetycki rozpoczyna się słowami: „Widziałam ogród na żywym cmentarzu, na którym śniły posągi...”25. Późniejsze zdania stopniują nastrój grozy, w przestrzeni pojawiają się „rosnące szubienice” („halfa nőnek”), „olbrzymie fioletowe orły” („nagy, lila sasok”) i „szybujące koty” („macskák nagy szárnnyal”), a człowiek przedstawiany jest jako ten, którego modlitwa „nie sięga już nieba”, ponieważ jego zawodzenie zamarza „w jęzorach lodowca” („jeggé fagynak [...] s gleccserré nőnek” ${ }^{26}$. Zaburzona rzeczywistość „niemego wycia”, złowieszczych szeptów, oklasków współbrzmiących z szumem wiatru wiejącego nad „błotami cuchnącymi śmiercią”, ma dowodzić istnienia świata, w którym nie panują żadne z dotąd znanych praw (ani moralne, ani fizyczne). Liryczne „ja” $\mathrm{z}$ inicjującego utwór fragmentu poetyckiego zadaje wreszcie filozoficzne pytanie: „Czy ten ogród zniknie, kiedy skończy się sen?”27.

\footnotetext{
24 S. MÁndy: Egy halott álmaiból. „Múlt és Jövő” 2000, nr 3-4, s. 253.

25 Tamże.

26 Tamże.

27 Tamże.
} 
W kolejnej części pisarka nieoczekiwanie zmienia strategię, opuszcza na chwilę surrealną przestrzeń senną i krótko przybliża okoliczności powstania wizji, która, jak twierdzi, przyśniła się jej w marcu 1944 roku (czyli w miesiącu zajęcia kraju przez Trzecią Rzeszę i przystąpienia Węgier do wojny). Mándy podsumowuje rozdział „Rzeczywistość” słowami:

Tamtej nocy moje dzieciństwo przesypało mi się przez palce jak mąka z pękniętego worka. Obudziłam się oblana potem, gardło ściskał mi ogromny strach przed śmiercią. Włączyłam lampę. Była trzecia nad ranem. Bosa, trzęsąc się z przerażenia, chwyciłam za pióro i spisałam starannie caluteńki sen. Kilka dni później wszystkich nas, małych i dorosłych, wierzących i neofitów [...] skazano na śmierć, staliśmy się ofiarami ${ }^{28}$.

Późniejsze partie tekstu (rozdział „Sen”) powracają do nierealnej rzeczywistości, która budowana jest na podstawie pozornie realnych scenerii i zachowań, przełamywanych jednak nieoczekiwanymi symbolami i surrealnymi rozwiązaniami. Wizje Mándy łudzą prawdopodobieństwem, by nieoczekiwanie wtrącić czytelnika w niepokój obrazu. Narratorka wspomina na przykład chwilę, kiedy, zmęczona wojną, „żegnała się z tym, czym była i kim mogła się stać”29, i nagle jej wzrok przykuła postać pół mężczyzny, pół baranka; dręczył go oficer, trzymał kopytną istotę pod wodą, a w ostatniej chwili uniósł narzędzie tortur i ocalił ofiarę. Scena kończy się strzałem wojskowego w kierunku krzyczącej narratorki, która - w kolejnej partii tekstu - zdaje relację z bycia zastrzeloną („przeszła przeze mnie wyczekiwana, gorąca kula”) ${ }^{30}$.

Sekwencje pojawiające się tuż po strzale, kiedy narratorka unosi się w powietrze i szybuje nad ziemią, zaczynają się układać w ciąg znaczących obrazów, nawiązujących do obozowej rzeczywistości: pojawiają się „ogromne tłumy ludzi na drodze”, „cuchną bagna”; liryczne „ja” stwierdza wreszcie: „jestem w piekle” 31 , na co napotkany człowiek (o nieokreślonej płci) wykrzywia twarz w grymasie, pytając: „Z czego się cieszysz? [...] Ja nie żyję, ty nie żyjesz. Nie ma zmartwychwstania. To stacja końcowa [...]”, a kobieta spotkana na „cmentarzu żywych” nosi na plecach „międzynarodowy symbol życia i śmierci - czerwony krzyż” i uspokaja narratorkę, gdy ta próbuje wezwać lekarza: „Tutaj nie potrzeba lekarza [...]. Głodzimy chorych, aż umrą [...]. Nie ratujemy przed tym, co nieuchronne"32.

Kolejne sceny ukazują coraz większe napięcie i grozę, postaci zaludniające wizje podróżują w trumnach na kółkach, lamentują, błagają o wodę, która wcieka do środka skrzyń przez wąskie szczeliny. W końcu rozlega się krzyk: „Gaz!”. Narratorka wyznaje:

\footnotetext{
28 Tamże, s. 254.

29 Tamże.

30 Tamże.

31 Tamże, s. 255.

32 Tamże.
} 
Sparaliżowana czekałam na to, co się wydarzy. Niby byłam martwa, ale śmierć mnie przerażała. Długo nic się nie działo. Potem szczęknęły zawiasy, podniesiono wieko naszej trumny. I to, co zobaczyłam, ścisnęło mi serce. Po prawej i lewej stronie peronu ciągnęły się w nieskończoność druty kolczaste. [...] Na całym terenie czuć było jakiś straszny, duszący odór. Pojęłam. Trafiliśmy do samego centrum cmentarza żywych ${ }^{33}$.

W wizji zapada już mrok rozświetlany jedynie potężnymi płomieniami jaśniejącymi wokół stosu, pochód przybyszów ciągnie w stronę ognia. Pojawiają się odczucia cielesne - koryfejka po piekle wyznaje, że cierpi niewygodę, ponieważ ludzie stoją stłoczeni w wąskiej piwnicy, cierpną jej ręce i nogi, odczuwa silny ból - ktoś ogryza jej ucho. Więźniowie duszą się z braku powietrza, drapią paznokciami gołe ściany pomieszczenia, „stłoczeni”, „miażdżeni”, „sprasowywani”, „pędzeni”, „ugniatani”" ${ }^{34}$ W końcu, przed wyjściem na zewnątrz, polewa się ich wrzątkiem, zrywa włosy. Wszyscy są już łysi i nadzy, z otwartymi przez gorącą wodę, palącymi ranami.

Wszystkie te sceny to surrealne metafory obozowego losu, obrazujące podróż („trumna na kółkach”), błaganie o wodę, rampę, kolejkę do selekcji, łaźnię, golenie włosów, pędzenie nago, zagazowywanie. Sam obóz skrywa się pod nazwą Wyspa (Sziget), jest przestrzenią odseparowaną, otoczoną zasiekami.

Żyłam w świecie, w którym zniknęło to, co było do powiedzenia w poprzednim życiu, słowa się zużyły, zniekształcił się ich sens, „ja” też wypadło ze swoich ram, ludzi nie dzieliła już żadna granica ${ }^{35}$.

W końcowych partiach wizji, kiedy Mándy opisuje język komunikacji bohaterów, pojawia się sygnalizowany wcześniej problem „prymatu słowa”. Początkowo dźwięki wydawane przez istoty zamieszkujące Wyspę są niezrozumiałe, mieszczą się raczej w rejestrze zwierzęco-ludzkich odgłosów, ich głosy okazują się bowiem "ochrypłe” (rekedt), przeważnie „piszczą”/,jąkają się” (makog), a dopiero z czasem któryś z dźwięków przypomina „ludzkie słowo” ${ }^{36}$. Narratorka relacjonuje proces przyswajania tych głosów i przemiany świadomościowej, która po kilku dniach skutkuje całkowitą „niepamięcią o tym, kim się było” przed trafieniem na Wyspę.

Zmienia się także odczuwanie ciała, ponieważ na Wyspie wszyscy funkcjonują w stłoczeniu, przebywają w ciemnej piwnicy ${ }^{37}$, nie ma świeżego powietrza,

33 Tamże, s. 256.

${ }^{34}$ Tamże.

35 Tamże.

36 Tamże, s. 257.

${ }^{37}$ Mándy nie precyzuje, z jaką przestrzenią mamy tutaj do czynienia, czy Wyspa to umowna nazwa piwnicy. Przed dotarciem na Wyspę i na samej Wyspie „istoty” przebywają w piwnicy, która jest otoczona drutem kolczastym. 
stale się duszą, jest ich tylu, że nie mogą nawet swobodnie unieść rąk. Ciasnota wymusza wypracowanie rytuału, przyjęcie „wspólnego oddychania” (lélegzetvétel) i „wspólnego rytmu istnienia” (életrítmus). Tłum więźniów ma jeden puls ciała, żyje „jak mechanizm” (gépezett), staje się żywą, oczekującą śmierci retortą. To zespolenie, splecenie niekiedy przemienia się w obłędny taniec ( $v i-$ tustánc), twarze wykrzywia wtedy przerażający grymas, a nieprzewidywalna choreografia rozpaczy staje się przyczyną śmierci tych, którzy nie umknęli przed rozpędzonym w tańcu tłumem.

W wizji pojawiają się też obrazy związane z materią: błotny deszcz i żółta ciecz w wiadrze. Mieszkańcy Wyspy wychodzą na zewnątrz i widzą niekończące się ogrodzenie, niezamieszkałą połać, do której napływają nowi przybysze. Nieoczekiwanie okazuje się, że w tej przestrzeni można odnaleźć uskrzydlone ryby pływające w żłobach, nieznośną ciszę nocy przeszywa świst skrzydeł potężnego Nietoperza, w cuchnącym pyle gdzieniegdzie rośnie pokrzywa, a do uszu więźniów dochodzi ćwierkanie wróbla.

Można odnieść wrażenie, że Mándy postanawia niepostrzeżenie przybliżyć swoją abstrakcyjną wizję do realnych wspomnień. Zmienia się opis zachowań mieszkańców i okazuje się, że nie są już bezpłciowymi istotami, ponieważ pojawia się wśród nich doświadczona pielęgniarka i trzyletni chłopiec, który częstuje się czekoladą, a później zostaje pchnięty w kierunku „mechanicznego potwora” (metafora krematorium). Narratorka jest świadkiem publicznej egzekucji jednego z więźniów. Mówi o tym: „Tego zdarzenia też nie pojmuję: pierwszy raz widziałam umieranie zmarłego" 38 . Gdy na Wyspę trafiają przybysze i każe się im kilka dni czekać w upale, śniące „ja” potajemnie nosi im zaczerpniętą $\mathrm{z}$ basenu wodę. Cowieczorne apele wieńczone odliczaniem więźniów stają się prywatnym metrum upływającego czasu, narratorka mówi o latach spędzonych w tej przestrzeni, potrafi krytycznie ocenić własną sytuację, ponieważ dostrzega „Zwierzęcość zachowań”, „bycie zniewolonym”39. W końcu Mándy przemyca do tekstu filozoficzny wywód o radzeniu sobie w obozie:

[...] trzeba było czekać. Czekać, aż nadejdzie wieczór, aż nadejdzie świt, doczekać wiosny, już sama nie wiem czego jeszcze, może zmartwychwstania. Przestaliśmy tak w miejscu kilka tygodni, miesięcy. Sądziliśmy, że odpadną nam członki, że pęknie nam kręgosłup, za dnia myśleliśmy, że już mamy dość, a nocą, że zamarzniemy, a kiedy deszcz zmoczył nas do suchej nitki, czuliśmy, że nasze skarlałe ciała rozpadną się w gnijącej wodzie. Staliśmy lub klęczeli miesiącami i nie widzieliśmy śladu naszej męki, wiedzieliśmy jedynie, że nie ma ucieczki ${ }^{40}$.

\footnotetext{
${ }^{38}$ S. MÁndy: Egy halott álmaiból..., s. 259.

39 Tamże, s. 260.

${ }^{40}$ Tamże.
} 
Narratorka uzupełnia swoją relację, pisząc o samobójcach, którzy szukali drogi wyjścia, tuląc się do drutów podłączonych do wysokiego napięcia, o ciężarnej kobiecie, która, chcąc uprzedzić gest Nietoperza, sama odebrała sobie życie („płynęła w powietrzu”) ${ }^{41}$.

W ostatnich akapitach prozy poetyckiej Mándy w symboliczny sposób „opuszcza” wizję. Pisze: „[...] moje słowa już nie mogły nadążyć za piętrzącymi się, po-

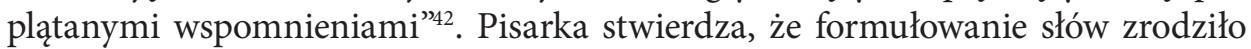
się z potrzeby „odcięcia się od samotności”, odczuwanej w nieprzebranym tłumie skazańców, z którymi łączyła ją przymusowa więź. Największym marzeniem było „Zrzucenie $\mathrm{z}$ siebie [...] przytłaczającego ciężaru, marzyła o przedostaniu się na drugi brzeg, by chociaż przez jeden dzień, przez godzinę znów być człowiekiem, który ma osobne istnienie, własny umysł, własną wolę. Tym byłaby wolnośc'" $\mathrm{W}$ finalnych zdaniach końcowego fragmentu pojawia się wymowna metafora doświadczenia obozu: nagle, bez najmniejszego ostrzegawczego odgłosu uderza w ziemię, tuż obok leżącej kobiety, „potężny, płonący meteor”. Kawałek skały wbija się w podłoże, rozrywa glebę, pustoszy miejsce wokół, ale „nie zabija jej potężna masa humusu, nie dusi się trującymi gazami, nie pali jej lawa wydobywająca się $\mathrm{z}$ wnętrza planety"44. Ten wstrząs przenosi narratorkę przed dom rodzinny, który rozbrzmiewa odgłosami kroków zmarłego ojca. Kobieta już wie, że jej słowa mają moc wyważania i rozbijania (feltörö) istniejącego porządku.

Do swojej nowatorskiej wizji Mándy dopisała w 1994 roku Posłowie, dobudowując do wcześniejszego fragmentu znaczeniową klamrę. Był to krótki komentarz dotyczący poetyki snu i symetryczny względem początku tekstu fragment poetycki:

Budząc się [z naszego snu - K.P.J.], dostrzegliśmy w naszych oczach to okropieństwo, tę niemożliwą do wyobrażenia sobie rzeczywistość, od której wielu $\mathrm{z}$ nas nie zdołało uciec. Chmury dymu nie skamienieją, by stać się wspomnieniem. Z Auschwitz można zmartwychpowstać jedynie w języku. Cud dokonać się może jedynie w sile nazywania ${ }^{45}$.

Holenderskie drewniaki stukam rytm w los ślepy niczym kamienie me ręce drewniaki dwa ruszam boso w stronę śmierci wielkiej A potem przewrót na drążku
${ }^{41}$ Tamże.
42 Tamże.
43 Tamże.
${ }^{44}$ Tamże, s. 261.
${ }^{45}$ Tamże. 


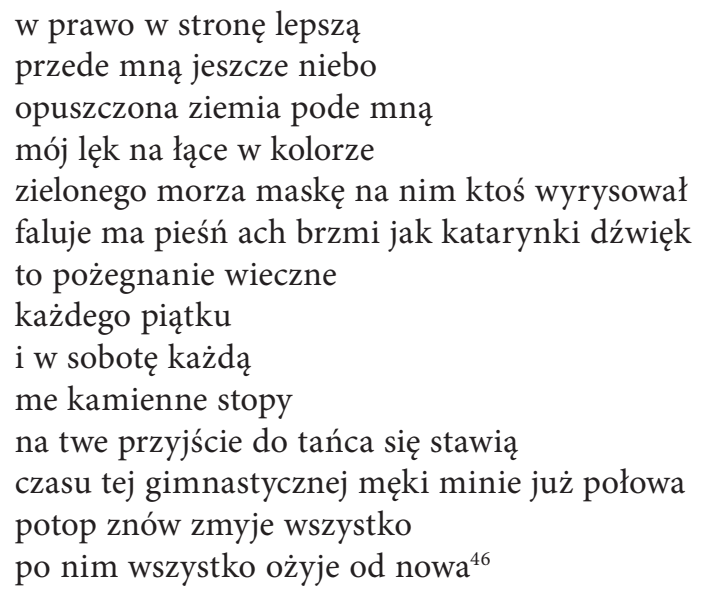

Referowane sceny, metaforyczne przestrzenie i zdarzenia z prozy Mándy układają się w jedną z najoryginalniejszych kreacji artystycznych poświęconych Zagładzie w literaturze węgierskiej. Pisarka, jak zapowiadało motto Tábora, nieustannie „mierzy Auschwitz”, posługując się jednostkami wyobraźni i moralności, które - ponieważ są zachwiane, wypaczone, zburzone, nieodwracalnie naruszone - pomieścić może w podobny sposób zniekształcona przestrzeń, w tym przypadku surrealna wizja.

Zdaniem Anny Marczisovszky, tekst węgierskiej autorki stale „odnosi się do skojarzeń biblijnych [...], a przez to zyskuje uniwersalne znaczenie”" ${ }^{\prime 4}$, ponieważ punkt wyjścia stanowi krąg apokaliptycznych obrazów. Na przykład figura Nietoperza jest domyślnie interpretowana jako wcielenie Zła, a zachowania ludzi traktuje się jako projekcję przefiltrowanej przez sztukę pamięci: Wyspa jest obozem, Cudowny lekarz to doktor Mengele, trumna na kółkach i spragnieni wody to podróżujący do obozu ludzie etc.

Kluczowe wydaje się jednak połączenie „Ze snów umarłej” z późniejszymi tomami poetyckimi, które László Vöröss odczytywał jako „jeden wielki monolog liryczny" ${ }^{\prime 8}$. Taki koncept lekturowy, dodatkowo wsparty brakiem datowania utworów, pozwalałby łączyć powtarzające się idee, obrazy doświadczenia żydowskiego, metafory trudnej obecności na łonie węgierskiego społeczeństwa w spójny, choć polifoniczny głos pamięci. Lektura holistyczna pozwalałaby także dostrzec ewolucję pojedynczych myśli, które dopiero w rozproszonych tekstach o Zagładzie,

46 Tamże.

47 A. Marczisovszky: „Az út többé fem fogy el”. Mándy Stefánia Auschwitz-prózája. In: Zsidó identitáképek a huszadik századi magyar irodalomban. Szerk. G. Scheın, T. Szúcs. Budapest 2013, s. 200.

48 L. VöRöss: „mert minden óra végső óra”. Mándy Stefánia válogatott és új versei, költői életmüve. „Új Forrás” 2005, nr 5. Dostępne w Internecie: http://epa.oszk.hu/00000/00016/00055/000 515.htm [data dostępu: 15.04.2019]. 
a mam tu na myśli przede wszystkim wiersze Soá, Szentendrei orátoriumból, Sztéle, Agnus Dei oraz cykl utworów poświęconych Milenie Jesenskiej (K. Prágából Bécsbe, Milena leveiböl I, Milena leveleiböl II), doczekały się ukonkretnienia, chociażby geograficznego, pojęciowego. Można powiedzieć, że Mándy potraktowała swój pierwszy tekst o obozach jako eksperyment formalny, ponieważ opisała pobyt w Auschwitz, wykorzystując środki surrealnego zaburzenia czasowo-przestrzennego, swoją znakomitą wiedzę o poezji i malarstwie awangardowym, opierając się głównie na osiągnięciach wyobraźniowych Lajosa Kassáka, Endre Bálinta, Ferenca Martyna, Lili Ország, Júlii Vajdy, a przede wszystkim na pracach Lajosa Vajdy. Wymienieni twórcy konsekwentnie przełamywali decorum artystyczne, pokazując Zagładę językiem nieoczekiwanych symboli. Najsłynniejsze grafiki Endre Bálinta (na przykład Holocaust, 1977; Menóra és motívumok, 1977), szkice tuszem Ferenca Martyna (A fasizmus szörnyetegei, 1944) czy cykle prac Lili Ország (na przykład Kihalt város. Rekviem, 1963) kontynuowały linię płócien i szkiców zainicjowanych przez Imrego Ámosa, artystę pochodzenia żydowskiego, zamordowanego podczas robót przymusowych w obozie niemieckim w Ohrdrufie latem 1944 roku. Ámos jako pierwszy rysował grafiki obrazujące tożsamość, w stylu Chagalla na wzór kubistycznego splątania konturów i faktur, przeplatając symbole żydowskie symbolami apokaliptycznymi. Idea ta stała się bliska węgierskim artystom plastykom, którzy po wojnie zmagali się z podobnym problemem, co pisarze. Wybór surrealnej estetyki pozwalał im mówić o doświadczeniu wymykającym się tradycyjnej reprezentacji, które musi być przemycane do sztuki, zakamuflowane pod konkretnymi i czytelnymi dla wytrawnego oka metaforami.

W kontekście zróżnicowanej sztuki grafików i malarzy twórczość Mándy określić by można jako literackie wcielenie koncepcji obecnej wśród węgierskich plastyków. Poetka postanowiła opowiedzieć o doświadczeniu tak, jak je przeżywała, czyli na granicy rozpoznawalności i wyobraźni. Do tego sposobu odczuwania losu dostosowała język, który próbował naśladować wybraną estetykę - opowiadała o Auschwitz oksymoronami, bawiła się przestrzenią, zmieniała tempo narracji w zupełnie nieprzewidywalnym rytmie, oszukiwała wzrok i słuch, rozciągała ramy naturalizmu, aż otrzymywała niewyjaśnialne zniekształcenie. Niektórzy artyści węgierscy - György Román czy Imre Ámos poszukiwali podobnych rozwiązań w swoich dziełach, prezentując doświadczenia lagru, getta i prac przymusowych w estetyce surrealnej. Rezygnacja z naturalizmu nie oznaczała jednak odejścia od głównego imperatywu twórców, czyli dawania świadectwa. János Kőbányai w szkicu A holokauszt müvészete („Sztuka Holokaustu" $)^{49}$ podkreślał znaczenie warstwy poznawczej płócien zastępujących dokumenty historyczne. W obliczu braku omówień i przemilczania żydowskiego doświadczenia twórczość plastyczna pełniła funkcję informacyjną. Cykle tematycznych grafik poświęconych gettu (na przykład Gettó-rajzai („Rysunki z getta”)

${ }^{49}$ J. KőBÁnYaI: A holokauszt müvészete. „Múlt és Jövő” 2004, nr 1-2, s. 81-84. 
Ilki Gedő) czy pobytowi w obozie (Judaika 1944 Pétera Áldora) funkcjonowały jako fantomy pamięci, będąc jednocześnie formą terapii poprzez sztukę. Twórcy preferujący surrealne wizje, w odróżnieniu od surowych, czarno-białych rycin naturalistów, prezentowali odczucia poprzez eksperymenty kompozycyjne i kolorystyczne, łącząc misję informowania z bogatym zapleczem symbolicznym. To, co dla artystów węgierskich było jedną z popularnych praktyk, w literaturze, poza przykładem Mándy, nie znalazło kontynuatorów. Eksperymenty formalne i wyobraźniowe uchodziły za zjawisko rzadkie i niepopularne, traktowane jako złamanie decorum.

W refleksji nad sztuką wobec Zagłady, podobnie jak w literaturoznawstwie zajmującym się czasami wojny, pojawia się postulat uważnego interpretowania narzędzi artystycznych, co w przypadku robót plastycznych rzeczywiście miało wpływ na ostateczny kształt twórczości. Podczas robót przymusowych, w obozach koncentracyjnych czy w gettach artyści „mieli do dyspozycji prymitywne narzędzia" ${ }^{\circ 0}$, o czym najdobitniej świadczą prace Imrego Ámosa czy Endre Bálinta. Można jednak zauważyć, że wyraźny zwrot ku ascetycznemu symbolizmowi pojawił się dopiero w latach 70. wśród przedstawicieli drugiego pokolenia. Badacz sztuki Dániel Véri twierdzi, że „do stworzenia dzieł symbolicznych, pozwalających na odseparowanie się od pojedynczych wydarzeń [...] potrzeba dłuższego czasu” ${ }^{51}$, ale pojawili się przecież artyści, którzy umieli „zintensyfikować" doznanie czasu i tworzyć takie prace równolegle z wydarzeniami. Jednym $\mathrm{z}$ ważnych pojęć, które pozwalają zrozumieć ideę poszukiwania artystycznego (pisarskiego i plastycznego) języka, jest „narracja antyfaszystowska” ${ }^{2}$.

Véri, autor tego terminu, definiując go, podkreśla znaczenie perspektywy ofiar, związków sztuki z Zagładą, ale zatrzymuje się głównie na performatywnym znaczeniu wystaw, które - o czym pisałam wcześniej - stawały się częścią „Zastępczej narracji” o przemilczanej wojnie i żydowskim doświadczeniu. Wydaje się jednak, że można by rozszerzyć interpretację pojęcia „narracji antyfaszystowskiej”. Jeśli uwzględnimy narzędzia artystyczne, zwłaszcza te artefakty, które dowodziły wyjątkowej erudycji świadków-autorów, a także służyły manifestowaniu wyższości ich intelektu i postawy humanistycznej nad polityką narodowego socjalizmu, dostrzeżemy wyraźną i konsekwentną misję tej sztuki. Powstawała ona wbrew ideologii przemocy, mimo zagrożenia, do ostatnich minut życia (casus Miklósa Radnótiego), a przez to uparcie dowodziła przynależności do odległego, ale - jak chciano wierzyć - wciąż aktualnego świata wartości, w którym człowiek jest niezmiennie miarą wszechrzeczy.

${ }^{50}$ D. VÉRI: A holokauszt és a zsidó identitás szimbolikus ábrázolásai (1939-1960). Bálint Endre, Martyn Ferenc, Major János és Maurer Dóra grafikái. In: Szigorúan ellenörzött grafika 19451961 között. Szerk. G. PATAKI. Miskolc 2018, s. 40-41.

${ }^{51}$ Tamże, s. 42.

${ }^{52}$ Tamże. 
Sztuka i literatura dawały wyraz temu przekonaniu w różny sposób. Wykwit popisów intelektualnych mających potwierdzać przekonanie o krótkotrwałej przewadze polityki nazistowskiej (na przykład obecnych w wysmakowanych heksametrach Radnótiego pisanych podczas robót przymusowych) szedł w parze $z$ narastającym imperatywem dekonstruowania dawnego języka estetyk, które legły niegdyś u podstaw tradycji europejskiej. Przejawem takich przemian artystycznych było zerwanie $\mathrm{z}$ tradycją tonalną w muzyce.

\section{Partytura dekonstrukcji \\ A szentendrei óratoriumból („Z szentendreńskiego oratorium”)}

W jednym z tekstów Mándy, A szentendrei óratoriumból („Z szentendreńskiego oratorium”) z 1959 roku, widać ślady wszystkich opisanych wcześniej zjawisk. Na pierwszym miejscu autorka stawia bowiem wizje surrealistyczne, które przypominają opisy monumentalnych, apokaliptycznych obrazów; tworzy je za pomocą narzędzi językowych uwypuklających rozpad dotychczasowego świata (tutaj głównie oksymorony i nieoczekiwane kolokacje), a na dodatek wybiera dla swojego tekstu formę muzyczną, która wymusza budowanie konkretnych ram kompozycyjnych i formalnych. W utworze Mándy konsekwentnie demontuje misterną konstrukcję fenomenu oratorium, tworzy bowiem tekst przeczący definicji gatunku. Nie mamy tu już do czynienia $\mathrm{z}$ „wielką formą wokalno-instrumentalną”, ale z czteroczęściową próbą oddania głosu grupom „śpiewaków" (partie chóru, recytatywy i arie). Partie narracyjne zostały przeniesione do recytatywów, tekst nie ma tła muzycznego, a nawet można by powiedzieć, że mimo rozpisania na części teoretycznie dedykowane występom wokalnym okazuje się przeciwwzniosły, wykonuje się go czy - ściślej mówiąc - „odmawia za auschwitz ${ }^{53}$ w 1959 roku” ${ }^{34}$. Główną ideą wpisaną w ten utwór jest wykonanie performatywnego rytuału, który - mimo że mamy do czynienia z oratorium - nie odwołuje się do tematyki religijnej, chociaż można założyć, że dwudziestowieczne oratoria znały już świecką problematykę, więc nie był to warunek konieczny kształtujący format tematu.

Mándy, jak można sądzić, celowo powróciła do kwestii obozowych, by zamanifestować prywatną ewolucję sposobu myślenia o wojennym doświadczeniu. W „Z szentendreńskiego oratorium” narratorami są więźniowie, dawni mieszkańcy obozu, którzy przymierzają matryce kulturowe do tego, co zapamiętali

${ }^{53}$ Pisarka celowo pisze nazwę małą literą. Por. S. Mándy: A szentendrei oratóriumból (auschwitzért mondott anno 1959). In: TAż: A kés, a kéz, a hal..., s. 30-37.

${ }^{54}$ Tamże, s. 30. 
z Auschwitz. Seria zderzeń obrazów biblijnych i fraz religijnych z wizjami, które kreślą przed czytelnikiem, składa się w opowieść wypowiadaną niepełnymi, zawieszonymi lub przerywanymi zdaniami. Brakuje odpowiednich słów, więc wieloosobowa grupa (chociaż liczba uczestników oratorium nie jest określona) tworzy własny język, posługujący się przeważnie metaforami, ponieważ obrazy językowe opierają się na nietradycyjnych połączeniach wyrazów.

Najpierw Mándy definiuje dystans czasowy oddzielający partie recytatywu i arii od doświadczenia: „w miejscu nogi dawno wyblakł ból”, a odbiorcy mają skupić uwagę na „ślepej pieśni” prezentowanej pod „kulą słońca w kolorze żelaza" ${ }^{55}$. Pierwsze zdania służą więc ukonkretnieniu wizji świata, który kojarzy się wyłącznie z przestrzenią wojenną. Ten punkt widzenia zostaje przeniesiony nawet na obiekty astralne - słońce przypomina wystrzelony z broni palnej pocisk, a zdanie wypowiadane w pierwszej arii głosi, że „nie ma już pustki”. Wszystko, co dotyczy człowieka, porównywane jest do zniekształconych, klaustrofobicznych i wrogich przestrzeni oraz przedmiotów („zamknięte drzwi piwnicy”, „wahadło połyka nasze wykrzywione [...] odbicia"). Towarzyszami niedoli są tygrysy i leopardy, które - podobnie jak praludzie - wykonują dwie czynności: „płaczą i śmieją się ${ }^{35}$. W tle mija czas odmierzany według żydowskiego kalendarza:

Chór

niszan ijar siwan tamuz

dni nasze poszły na zmarnowanie

ciała wystarczy i duszy

śpiewaj teraz dawidzie dawidzie ${ }^{57}$

Kolejne strofy intensyfikują wymowę metafor. Recytatywy i arie przywołują „piramidy czaszek”, „bijące blaskiem ostrosłupy kości”, nad którymi góruje „blaszana podobizna Jezusa”, „metalowa maska”, „pordzewiałe arkusze papieru”58. Do tych wizji powraca się, by rozpamiętywać przeszłość na scenie w kolorze krwi, co zmusza do przypomnienia sobie, że ,jesteśmy ludźmi”. Nagromadzenie ułamków doznań, wyrażanych często neologizmami, które trudno odszyfrować, finalizuje konstatacja: „dawid dawid nie śpiewa” ${ }^{59}$.

Wyraźne odwołania do tradycji judeochrześcijańskiej (Jezus, Dawid) domykają etap definiowania pozycji narratorów oratorium: wypowiadają się świadkowie, uczestnicy, którzy, odnosząc własne doświadczenia do religijnych korzeni Europy, odnotowują milczenie i pustkę wokół nich. Poczucie osamotnienia

\footnotetext{
55 Tamże, s. 30.

56 Tamże.

57 Tamże.

58 Tamże, s. 31.

59 Tamże.
} 
i zagubienia w zaburzonym świecie („zmarło światło, ale żyje ogień”, „niebo jest ciemne" ${ }^{\prime \prime}$ ) prowadzi do kolejnych wizji. Głowy świadków kołyszą się między chmurami, a wokół nich łopocze "nagość ubrana w płaszcz w kolorze indygo" ${ }^{1}$. W miejscu, gdzie nie docierają ziemskie głosy, pojawiają się osobiste głosy, które autorka znowu zderza z biblijnymi obrazami.

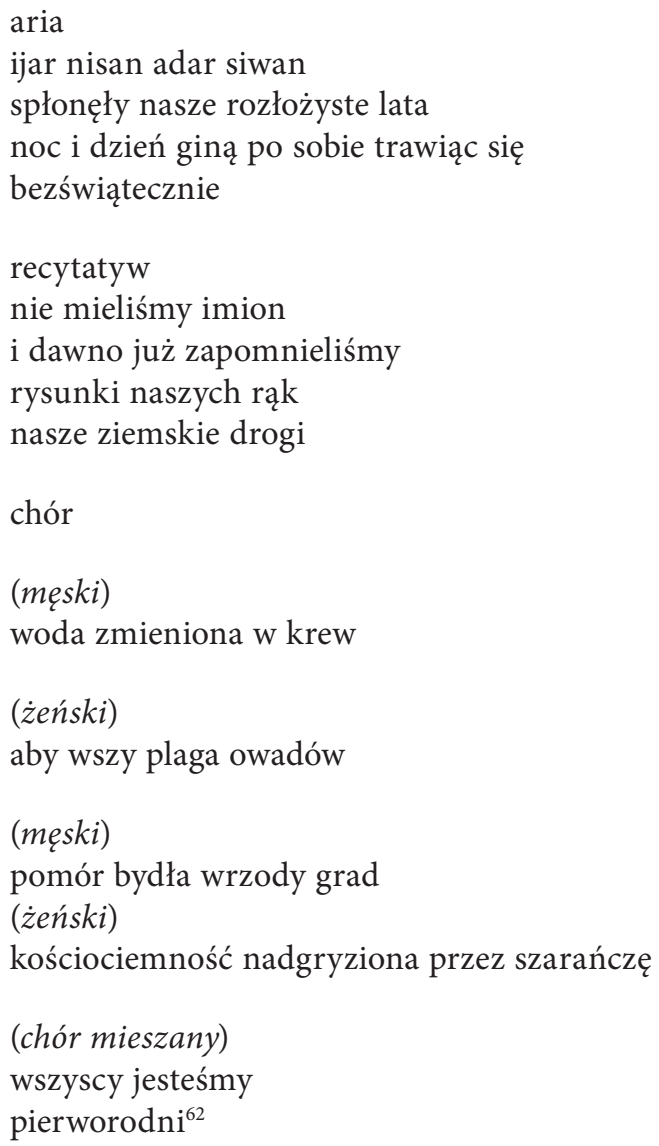

Po przywołaniu dziesięciu plag egipskich narratorzy arii przenoszą się znowu do „nieoznaczonego grobu”, do „piasku słów”. W oczach zmarłych odbija się „płonąca rana niekończących się pochodów”. Idący w Marszu Śmierci „nie mają ani imienia, ani twarzy"63, ponieważ niczego już nie ma, nawet śmierci. Mimo wyraźnych odniesień obozowych pojawia się coraz więcej uwag dotyczących współczesności:

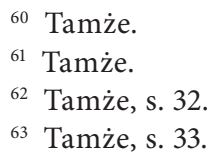

${ }^{63}$ Tamże, s. 33. 


\author{
recytatyw \\ lata minęły i tysiąclecia \\ milczały ziemie i ściany \\ milczały drzewa i odnogi rzek \\ spalone sarny wyschnięte morza $[\ldots]^{64}$
}

Część trzecia oratorium tworzy nowe metafory istnienia byłych więźniów: „dręczącą polifonię”, "głód tworzenia”, bowiem o „pragnieniu mówi każda nasza pieśń"65. Można to kluczowe pojęcie interpretować na kilka sposobów. Poza oczywistym, bo wpisującym się w konwencję wcześniejszych religijnych przywołań, metafizycznym pragnieniem wyraźnie nawiązuje ono także do gestu artystycznego. Słychać tu bowiem echo słów legendarnego wiersza Jánosa Pilinszkyego „Francuski więzień” (1946-1958) ${ }^{66}$, w którym poeta, wspominając scenę kradzieży jedzenia w obozie, snuł filozoficzną refleksję o wiecznym głodzie egzystencjalnym:
„Jestem głodny”. - I nagle mnie dopada
jemu nie znany, nieśmiertelny głód,
którego ziemska nie złagodzi strawa,
uciekłeś przed nim już, nędzarzu mój.
Dziś żyjesz mną! Zachłanność twoja rośnie
i szczeznę sam, nim ją zaspokoję!
Ten, który zwykł obywać się czymkolwiek, już dłoń wyciąga po serce moje ${ }^{67}$.

Głosy chóru w oratorium Mándy życzą sobie, „żeby [pragnienie] zostało z nimi na zawsze" 68 , ponieważ opowiadając o wojnie, mogą mówić o sobie. Potrzebę tę uzasadnia powtarzający się motyw bycia przemilczanym, zmarginalizowanym. W arii narratorzy głoszą: „płaczą po nas ptaki i ryby” "Można zadać więc pytanie: co to pragnienie mówi o zakwestionowanej instancji metafizycznej, o Bogu? W finalnych partiach chóru z części czwartej czytamy: „boże zawołaj dawida”, a dalej: „kiedy już nas nie będzie, nikt już ciebie nie wspomni”70. Oratorium zamyka mantryczna, trzy razy powtórzona fraza „gospodi pomiluj”71.

64 Tamże, s. 34.

65 Tamże, s. 35.

66 J. Pilinszky: Harmadnapon. Versek. Budapest 1959.

67 Brzmienie ostatniej strofy wiersza podaję za: J. Pilinszky: Apokryf. Wybrał, przeł. oraz wstępem opatrzył J. SNopek. Sejny 1999, s. 48.

68 S. MÁndy: A szentendrei oratóriumból..., s. 36.

69 Tamże.

70 Tamże.

71 Tamże, s. 37. 
Wyraźnie widać tutaj kolejną próbę definiowania ram świata przedstawionego, a zwłaszcza jego luk, zniekształceń aksjologicznych czy kulturowych. W rzeczywistości tekstu projektowanego przez Mándy głosy z recytatywów, chóru i arii przebywają w świecie bezludnym, postapokaliptycznym, są prawdopodobnie ostatnimi ludźmi na ziemi. Zdradzają także wyjątkową umiejętność dostrzegania i analizowania rzeczywistości za pomocą samodzielnie wypracowanych narzędzi. Są nimi: gry językowe, świadomość historyczno-społeczna, żonglowanie matrycami kulturowymi, sprawne włączanie symboli i mikrocytatów. W przypadku oratorium, podobnie jak w „Ze snów umarłej”, możliwych jest kilka równorzędnych, równoprawnych lektur. Jednym z najciekawszych tropów byłby żywioł poetycki wyrażany w niezwykłej plastyczności genologicznej tekstu, ponieważ poszczególne części obu utworów reprezentują różne gatunki literackie.

Pisarka celowo wybrała estetykę surrealną, jej głównym celem była bowiem konfrontacja sztuki ze społeczeństwem odrzucającym tradycyjne formy narracji wojennych, unikającym debaty na temat własnego udziału w wojnie. W obliczu nieprzezwyciężalnego milczenia Mándy zdecydowała się na awangardową wyobraźnię, sekretny zapis obrazów zbyt wstrząsających, by rejestrować je bez narzędzi literackich. Takie pisanie było formą ratowania samej siebie, osłaniania się przed wiedzą, która niszczyła, ale przede wszystkim czytelnym znakiem literackiego kunsztu.

\section{Bibliografia}

A Holokauszt és a családom. Szerk. K. Fényes, M. Szalay. Budapest 2015.

Aleksijewicz S.: Wojna nie ma w sobie nic z kobiety. Przeł. J. Czech. Wołowiec 2010.

Cixous H.: Śmiech meduzy. Przeł. A. NasiŁowska. „Teksty Drugie” 1993, nr 4/5/6, s. $147-166$.

JuHász A.: „A csonka csönd szólni marasztal”. Mándy Stéfánia pályaképe. „Mühely” 2001, nr 6, s. 32-38.

KaCandes I.: "When Facts are Scarce". Authenticating Strategies in Writing by Children of Survivors. In: After Testimony. The Ethics and Aeastethics of Holocaust Narrative for the Future. Eds. J. Lothe, S.R. Suleiman, J. Phelan. Ohio 2012, s. 162-197.

Katz N.: Konvergencia. In: Sós kávé. Női elmesélhetetlen történetek I. Szerk. K. PÉcsI. Budapest 2007, s. 145-148.

KöBÁNYAI J.: A holokauszt müvészete. „Múlt és Jövő” 2004, nr 1-2, s. 81-84.

KöBÁNYAI J.: A magyar-zsidó irodalom története. Kivirágzás és kiszantás. Budapest 2012. MÁndy S.: A kés, a kéz, a hal. Párizs 1970.

Mándy S.: A lélek lép, lebben suhán. Budapest 1941.

MÁNDy S.: Az ellopott történelem. Versek 1944-1992. Budapest 1992.

MÁndy S.: Egy halott álmaiból. „Múlt és Jövő” 2000, nr 3-4, s. 253-261. 
Mándy S.: Mozaikrészecskék egy Egészhez. Tábor Béláról. „Szombat” 1995, nr 7. Dostępne w Internecie: https://www.szombat.org/archivum/mozaikreszecskek-egy-egeszhez [data dostępu: 20.02.2019].

Mándy S.: Scintilla (versek). Budapest 1999.

Marczisovszky A.: „Az út többé fem fogy el”. Mándy Stefánia Auschwitz-prózája. In: Zsidó identitáképek a huszadik századi magyar irodalomban. Szerk. G. Schein, T. SzÜCs. Budapest 2013, s. 191-206.

Menyhért A.: A nöi irodalmi hagyomány. Erdős Renée, Nemes Nagy Ágnes, Czóbel Minka, Kosztolányi Harmos Ilona, Lesznai Anna. Budapest 2013.

PÉCsI K.: Hallgatások és elhallgatások útvesztőjében. A szerkesztő elöszava. In: Lányok és anyák. Elmeséletlen női történetek II. Szerk. K. PÉcsi. Budapest 2013, s. 7-10.

Petö A., Hecht L., Krasuska K.: Introduction. In: Women and the Holocaust: New Perspectives and Challenges. Eds. A. Рetö, L. Неснt, K. Krasuska. Warszawa 2015, s. 9-24.

Pilinszky J.: Apokryf. Wybrał, przeł. oraz wstępem opatrzył J. Snopek. Sejny 1999.

Pilinszky J.: Harmadnapon. Versek. Budapest 1959.

Piotrowiak-Junkiert K.: Eksperyment socjograficzny w narracji kobiecej o Zagładzie: Teréz Rudnóy „Szabaduló asszonyok”. A szabadság első 24 órája. In: A hungarológia ma: nyelvészet, kultúra és oktatás - Hungarologia dzisiaj: językoznawstwo, kultura i dydaktyka. Szerk. I. Koutny, K. Piotrowiak-Junkiert, P. Kornatowski, Sz. NéMETH. Poznań 2017, s. 281-288.

Szegedy-Maszák M.: A bizony(talan)ság ábrándja: kánonképződés a posztmodern korban. In: M. Szegedy-MAszÁK: „Minta a szönyegen”: a müértelmezés esélyei. Budapest 1995, s. 76-89.

ТÁвоR B.: A zsidóság két útja. Budapest 1939.

TÁвоR B.: Szakzsidóság vagy zsidó világnézet. „Ararát” 1943. Dostępne w Internecie: http://lajosszabo.com/SZEL/szakzsidosag.pdf [data dostępu: 08.04.2019].

Tydor-Baumel J.: Gender and Family Studies of the Holocaust: the Development of a Historical Discipline. In: Life, Death, Sacrifice. Woman and Family in the Holocaust. Ed. E. Herzog. Jerusalem-New York 2008, s. 21-36.

VÉRI D.: A holokauszt és a zsidó identitás szimbolikus ábrázolásai (1939-1960). Bálint Endre, Martyn Ferenc, Major János és Maurer Dóra grafikái. In: Szigorúan ellenőrzött grafika 1945-1961 között. Szerk. G. PATAKi. Miskolc 2018, s. 40-69.

Vöröss L.: „mert minden óra végső óra”. Mándy Stefánia válogatott és új versei, költői életmüve. „Új Forrás” 2005, nr 5. Dostępne w Internecie: http://epa.oszk. hu/00000/00016/00055/000515.htm [data dostępu: 15.04.2019]. 
Kinga Piotrowiak-Junkiert

\section{The Surreal Shoah}

On Stefánia Mándy’s "Egy halott álmaiból”

("From the Dreams of the Dead Woman")

Gender Studies and the Hungarian Poetry on the Holocaust

\section{Summary}

This article is devoted to Stefánia Mándy’s "Egy halott álmaiból” ("From the Dreams of the Dead Woman"), a text that has met little attention so far. Facing the experience of the Shoah, the Hungarian author presents a poem that consists of both poetic and narrative fragments. In search of a language capable of telling or describing her own experiences adequately, Mándy decides to apply surrealism to her memories of a camp, contributing to the unique work that departs from the literary decorum.

Key words: women's literature, Hungarian poetry, Stefánia Mándy, surrealism, Holocaust 